NBER WORKING PAPER SERIES

\title{
THE IMPACT OF THE CIVIL WAR ON \\ CAPITAL INTENSITY AND LABOR PRODUCTIVITY \\ IN SOUTHERN MANUFACTURING
}

\author{
William Hutchinson \\ Robert A. Margo \\ Working Paper 10886 \\ http://www.nber.org/papers/w10886
}

\author{
NATIONAL BUREAU OF ECONOMIC RESEARCH \\ 1050 Massachusetts Avenue \\ Cambridge, MA 02138 \\ November 2004
}

An earlier version of this paper was given at the Economic History Association Meetings, in Nashville TN, September 2003. We are grateful to participants at EHA sessions and to Eric Bond and William Collins for helpful comments. The views expressed herein are those of the author(s) and not necessarily those of the National Bureau of Economic Research.

(C) 2004 by William Hutchinson and Robert A. Margo. All rights reserved. Short sections of text, not to exceed two paragraphs, may be quoted without explicit permission provided that full credit, including () notice, is given to the source. 
The Impact of the Civil War on Capital Intensity and Labor Productivity in Southern Manufacturing William Hutchinson and Robert A. Margo

NBER Working Paper No. 10886

November 2004

JEL No. N61, N91

\section{ABSTRACT}

The Civil War resulted in a substantial divergence in the regional structure of factor prices. In particular, wages fell in the South relative to the non-South, but interest rates and other measures of the costs of capital increased. Using archival data for manufacturing establishments, we show that capital-output and capital-labor ratios in southern manufacturing declined relative to non-southern manufacturing after the War, precisely in the direction implied by the regional shifts in factor prices. Labor productivity in Southern manufacturing also declined, but this decline is explained by the reduction in capital intensity.

William Hutchinson

Department of Economics

Vanderbilt University

Nashville, TN 37235

william.hutchinson@vanderbilt.edu

Robert A. Margo

National Bureau of Economic Research

1050 Massachusetts Avenue

Cambridge MA 02138

robert.a.margo@vanderbilt.edu 


\subsection{Introduction}

Recent work by economic historians has established that the Civil War was associated with a structural break in the regional pattern of wages (Wright 1986; Margo 2004). Relative to the North, wages in the South fell sharply in the immediate aftermath of the War. While there was some recovery in the South's relative position after the immediate decline, wages in the South remained persistently low long after the War had ended. However not all factor prices in the South moved downward after the War relative to those in other regions. In particular, interest rates, and related measures of capital costs, increased in the South relative to the non-South, and they remained relatively high for the remainder of the nineteenth century (Bodenhorn and Rockoff 1992).

Although previous work has documented these post-bellum shifts in the regional pattern of factor prices and has suggested a number of plausible reasons for these shifts, there has been limited attention paid to the economic consequences. This paper uses archival data at the establishment level to study regional differences in capital use in manufacturing before and after the Civil War. Using these data we show that, relative to manufacturing in other parts of the country, establishments in the South used less capital per unit of output and less capital per worker after the War than compared with before the War. The shifts in regional patterns of capital use are precisely in the direction that standard economic models of factor choice would predict in response to the changes in factor prices, assuming no change in the underlying technology. 
Using the same data we also demonstrate that output per worker in Southern manufacturing fell relative to output per worker in Northern manufacturing after the War, and that the bulk of decline in relative labor productivity can be accounted for by the decline in relative capital per worker. Economic historians have long known that per capita incomes in the South declined, absolutely and relative to the non-South, after the War (Engerman 1966, 1971). Debate over the causes of the relative decline in southern per capita income has concentrated primarily on the demise of the gang system and its attendant effects on labor productivity in Southern agriculture versus decreases in labor force participation among ex-slaves and shifts in world demand for cotton away from the South (Fogel and Engerman 1974; Ransom and Sutch 1977; Goldin 1979; Wright 1986; Moen 1992). This paper demonstrates that a portion of the decline in per capita income in the South occurred because of endogenous reductions in capital intensity in a sector manufacturing -- in which slavery was relatively unimportant before the War and in which the gang system played essentially no role.

\subsection{Wages, Interest Rates, and the Civil War}

A central feature of the economic history of the United States in the nineteenth century was the development of national markets in goods and in factors of production. For certain types of output, such as cotton and various manufactured goods, this process was well underway long before the Civil War, and was aided by key improvements in internal transportation, such as steamboats, canals, and expansion of the railroads (Cole, et.a. 1938; Taylor 1951; Fishlow 1965); indeed, for some such goods, output markets 
were international in scope. National markets for labor and capital were also in the process of developing, as evidenced by migration patterns and by regional differences in interest rates. Real wages in the 1820s and 1830s were higher in the Midwest than in the Northeast, and this was the direction of internal migration, that is, east to west. As population was redistributed away from the east, real wage differences between regions fell. Similarly, Bodenhorn and Rockoff (1992) provide extensive evidence showing that interest rate differences across regions were on the decline before the Civil War. Despite these ongoing processes, on the eve of the Civil War, the United States is better described as a collection of regional factor markets rather than a single unified national market, say, for labor. Positive or negative economic "shocks" to certain regions, could be expected to cause the regional structure of factor prices to diverge from its previous equilibrium. Depending on the size of the shock and the speed and nature of the response, the divergence could be transitory, or might persist for a considerable length of time.

The Civil War was surely the largest "shock" experienced by the nineteenth century American economy. At the aggregate level, the War was an economic disaster; national output grew considerably more slowly in the 1860s than in surrounding decades (Engerman 1966). As negative as the impact was at the national level, there is little doubt that, in relative terms, the shock was more severe in the South than in the North (Goldin and Lewis 1976). In both relative and absolute terms, Southerners bore a much larger share of the costs of war (directly, and in the form of foregone consumption). In particular, per capita income fell in the South between 1860 and 1870, absolutely and relative to the rest of the United States (Engerman 1966; Goldin 1979). Although growth in southern incomes eventually turned positive, convergence was very slow for the 
remainder of the nineteenth century. At the turn of the twentieth century, per capita income in the South was approximately half the national average, below the level that existed prior to the War (Margo 1995).

By definition, per capita income is a function of factor prices and per capita factor supplies. Therefore, if the Civil War "caused" a decline in per capita income in the South relative to other regions, it must be the case that factor prices or per capita factor supplies, or both, diverged in the South relative to other regions in a manner that cumulatively resulted in a decline in per capita income. Because factor prices appear to have been converging across regions before the War, it is plausible to hypothesize that this process was halted by the War; and that factor prices, like per capita incomes, diverged across regions after the War, perhaps for some time.

Recent work by economic historians provides evidence of such divergence in the case of wages and the cost of capital. Strictly speaking, the evidence on "capital costs" pertains to interest rates and related measures, which are only a component of the "rental rate"; that is, the annual cost of a unit of capital. However, there is little reason to believe that other components of the cost of capital moved in ways to offset the changes observed in interest rates; that is, movements in interest rates and related measures serve as plausible proxies for the rental rates.

In the case of capital, the evidence suggests that rental rates increased substantially in the South relative to the North after the War, while wages declined sharply (Bodenhorn and Rockoff 1992; Bodenhorn 2000, p. 154; Legler and Sylla 2003; Margo 2004). Hence, the wage-rental ratio in the South fell relative to the North after the War. Table 1 presents a sampling of the relevant evidence. The figures in the table are 
coefficients of a dummy variable taking the value 1 if the observation pertains to the post-bellum South, from regressions of the general form:

$$
\text { Ln } p_{j t}=\alpha_{j}+\delta_{t}+\theta(\text { South }=1 \text { and Year }>1865)+\varepsilon_{j t}
$$

In this specification $\mathrm{p}$ refers to a factor price (for example, the monthly wage of farm or common labor) in location $\mathrm{j}$ in year $\mathrm{t}$; the $\alpha$ 's are the coefficients of the location dummies; the $\delta$ 's are coefficients of time dummies; and $\varepsilon$ is the error term. The unit of observation is (typically) a state average, the sample covers the South and the North, and the data span the pre and post-bellum periods. Thus, if $\theta$ is positive, the factor price under analysis was generally higher in the South relative to the North after the War than before; and conversely, if the $\theta$ is negative. Later in the paper we use a similar specification to examine the "treatment effect" of the War on factor intensities in manufacturing.

As shown in Table 1, when the regression pertains to interest rates or the return on bank capital, the estimate of $\theta$ is positive and statistically significant; that is, interest rates in the South relative to the North were higher after the War than before the War. When the regression pertains to farm wages (see Margo 2004 for additional evidence on nonfarm wages) the coefficient is negative (and significant); wages were lower in the South relative to the North after the War than before. Consequently, the ratio of wages to interest rates, which we take as a proxy for the wage-rental ratio, fell sharply in the South relative to the North after the War, again compared with pre-war levels. 
Why did wages decline and interest rates rise in the South relative to the North after the War? The Civil War was an enormously complex event, and identifying all of the causal mechanisms at work is a daunting task. Because the War involved all regions of the economy and all economic sectors, even if it were possible to identify these mechanisms evaluating their effects quantitatively would require a general equilibrium analysis, one that is beyond the scope of this paper. For our purposes, however, it is possible to sketch out a list of the plausible conduits through which the changes in wages and interest rates occurred.

First, the Civil War was destructive of infrastructure and much of this destruction occurred on Southern soil. On a per capita basis, human and capital resources diverted to fighting were greater in the South, and these were, by definition, resources that did not flow towards replacement of the existing capital stock (depreciation) or new investment while the War was raging. Although some of the infrastructure was rebuilt after the War, it is plausible that the per capita stock of capital in the South did not fully recover from where it would have been in the absence of the War. That is, the aggregate supply of capital shifted inward, causing capital costs in the South to rise relative to those in other regions.

Second, the South was hit by financial shocks that led to a dramatic reduction in the number of banks and in the money supply on a per capita basis. One such shock was the loss of the War itself; the Confederate government collapsed and Confederate money and government bonds were worthless. In addition the National Bank Act of 1865 imposed an annual tax of 10 percent on state bank note issues after July 1 of 1866. Partly as a consequence of the Act, the number of state banks in the South in 1866 was 
only one-third those that existed on the eve of the Civil War, while the total number of banks stood at 60 percent of the pre-Civil War number. ${ }^{1}$ By 1880 the total number of banks in the South exceeded the pre-Civil War count in absolute numbers, but state banks remained approximately 50 percent of the total; and on a per capita basis, the total number of banks was below the pre-war level (Ransom and Sutch 1977). ${ }^{2}$ In Virginia, for example, the number of banks in operation in the late 1870s was only slightly more than half as large as on the eve of the Civil War. ${ }^{3}$

The upshot of these monetary developments was a severe contraction in per capita money in the South and a corresponding rise in interest rates. Money demand per capita in the South would have declined to some extent as a result of the decline in per capita income. ${ }^{4}$ However, the extent of the initial decline is breathtaking; the South went from a region that, on the eve of War, held per capita money some 30 percent above the national average to a region where per capita money in the immediate aftermath of the War was more than 90 percent below the national average.

Economic historians have considered a variety of explanations for the relative decline in Southern wages. It is known that labor force participation rates in the South appeared to have declined after the War, both absolutely and relative to the non-South (Ransom and Sutch 1977). Consequently, any explanation for the decline in relative wages must privilege a decline in relative labor demand rather than in relative labor

\footnotetext{
${ }^{1}$ Money is defined as currency plus bank deposits, where currency includes state bank notes per capita before the Civil War and National Bank notes after the Civil War. Deposits refer to total bank deposits at state banks before the Civil War and at both state and national banks after the Civil War.

${ }^{2}$ See John Jay Knox (1900) for detailed information on the number and location of banks.

${ }^{3}$ See Knox (1900). Declines in the absolute number of banks also occurred in North and South Carolina and Tennessee.

${ }^{4}$ On the other hand, money demand may have increased substantially, due to reduced availability of intermediaries and the increased level of economic uncertainty. Such increased money demand in the presence of limited elasticity of the money supply would produce a leftward shift of the LM curve, resulting in higher interest rates as well as lower aggregate demand and prices.
} 
supply. Possibly the most prominent explanation, although not the only one possible, is the loss of economies of scale in southern agriculture due to the demise of the gang system (Fogel and Engerman 1974; Goldin 1979; Moen 1992). According to this explanation, the loss of economies of scale reduced labor productivity in Southern agriculture and with it the demand for labor. Assuming that labor supply in the South was inelastic in the short run, a decline in labor demand would clearly reduce wages. Consequently, due to a combination of real and monetary shocks, the South emerged from the Civil War with a quite different factor price structure than before; compared with other regions, wages were lower, but interest rates were higher.

\subsection{Data and Results}

In section 2 we argued that the South experienced a substantial rise in interest rates - our proxy for capital costs -- relative to other regions after the Civil War, but a pronounced decline in relative wages. Simple economic theory predicts that these changes in factor prices should have affected factor use in production. As a point of departure, imagine two firms engaged in producing a specific product, one firm located in the South, the other in the North. For simplicity, we assume that both firms sell their output in a national or possibly international market and therefore face the same output price; however, factor markets are "regional" and, by assumption, the firms face (possibly) different factor prices. Both firms use the same technology which, for expository purposes, we assume is Cobb-Douglas. 
If the firms maximize profits, the first order condition for the optimal choice of the capital input is

$$
\mathrm{r}=\alpha_{\mathrm{K}} \mathrm{pQ} / \mathrm{K}
$$

The optimal choice of the capital-labor ratio is

$$
\mathrm{w} / \mathrm{r}=\left[\left(1-\alpha_{\mathrm{K}}\right) / \alpha_{\mathrm{K}}\right] \mathrm{x} / \mathrm{L}
$$

Letting an "S" denote the southern firm and an "N" the northern firm,

$$
(\mathrm{K} / \mathrm{Q})_{\mathrm{N}} /\left(\mathrm{K} / \mathrm{Q}_{\mathrm{S}}\right)=\mathrm{r}_{\mathrm{S}} / \mathrm{r}_{\mathrm{N}}
$$

and

$$
(\mathrm{K} / \mathrm{L})_{\mathrm{S}} /(\mathrm{K} / \mathrm{L})_{\mathrm{N}}=(\mathrm{w} / \mathrm{r})_{\mathrm{S}} /(\mathrm{w} / \mathrm{r})_{\mathrm{N}}
$$

There are three straightforward empirical implications of these first order conditions. First, as the cost of capital increased in the South relative to the North - an increase in $\mathrm{r}_{\mathrm{S}} / \mathrm{r}_{\mathrm{N}}$ - the capital-to-output ratio $(\mathrm{K} / \mathrm{Q})$ should decline in the Southern firm relative to that in the Northern firm. Second, as the wage-rental ratio in the South fell relative to the North, the capital-labor ratio in the Southern firm should decline relative to that in the Northern firm. Third, the reduction in the relative capital-labor ratio should be larger 
than in the capital-output ratio because, proportionately, the decline in the wage-rental ratio in the South was larger than the rise in the relative cost of capital. ${ }^{5}$

Our empirical analysis uses random samples drawn from the manuscript schedules of the 1850-80 federal censuses of manufactures for the United States (Atack and Bateman 1999). These schedules record the original responses of manufacturers (or their knowledgeable representatives) to questions posed by the census enumerators and the samples are nationally representative of the surviving manuscripts.

We use data on manufacturing for substantive and practical reasons. The substantive reason is that the technology of agricultural production in the South differed from that of the North prior to the War - the South utilized slave labor and, in certain crops, the gang system - and slavery was ended by the War. Consequently, identification of the causal channels in the case of agriculture is complicated by the fact that the technology changed which, by itself could affect the optimal choice of capital intensity, independent of any farm-level response to changing factor price ratios (see, however, Moen 1992 and the Conclusion). Although slaves were used in southern manufacturing before the War, their use was relatively minor and, more importantly, there is little reason to believe that the technology of manufacturing production was altered by the use of slave labor. The practical reason is that census data for manufacturing establishments spanning the ante-bellum and post-bellum periods for both the South and North are

\footnotetext{
${ }^{5}$ This prediction is sensitive to the assumption that the two firms face the same output price, despite being in different regions. If, instead, the output were non-traded, it is possible that $\mathrm{p}_{\mathrm{S}} / \mathrm{p}_{\mathrm{N}}$ might decline, in which case the proportionate rise in the real rental price of capital could be of the same order of magnitude as the decline in the wage-rental ratio. In fact, although the evidence is scanty, what there is suggests nontraded goods prices did fall in the South relative to the North (see Margo 2004). Empirically, however, what we observe is that capital-output ratios fell in the South relative to the North, and the magnitude of the decline was smaller in percentage terms than the decline in capital intensity (see the text).
} 
currently available, while analogous farm-level data for agriculture are not. ${ }^{6}$

Establishment level data are preferable to, say, aggregate state-level data because the establishment-level data allow us to control for a variety of attributes of firms that may affect capital use but which cannot be controlled for using published census information.

The censuses of manufacturing reported the value of "real and personal" capital invested in the establishment, along with information about each plant's outputs and inputs. The specifics of what was reported varied somewhat from census to census. All of them reported the value of outputs and raw materials. In 1850 and 1860, the number of male and female employees was reported but child workers were not separately identified. In 1870 and 1880, the number of adult males (over age 16), adult females (over age 15), and children were given.

Although the census samples are a valuable and under-utilized data source on nineteenth century manufacturing, there is no question that the information is problematic, particularly that for capital. Census enumerators were given no guidance, as far as we can tell, as to whether "value" meant book value or market value. However, the leading authority on the United States capital stock in the nineteenth century, Robert Gallman, argued that book value was uncommon at the time and that the capital figures refer typically to market value. ${ }^{7}$

It is unclear how - if at all — the censuses treated working capital. Although there is both circumstantial and direct evidence that working capital was not wholly omitted in

\footnotetext{
${ }^{6}$ Farm-level samples for both the South (Parker-Gallman) and North (Bateman-Faust) in 1860 are available, as is a farm-level sample for the South (Ransom-Sutch) in 1880 but, to our knowledge, there is no farm-level sample available for the North in 1880, nor are there samples for either region for 1870.

${ }^{7}$ See Gallman, “The United States Capital Stock," p. 174, and “Investment Flows,” pp. 220-22.
} 
1880 , it is possible that, on average, working capital was under-reported. ${ }^{8}$ Working capital, however, was definitely enumerated and its value reported separately in 1890 . Later in the paper we use the 1890 data to impute estimates of working capital as part of a sensitivity analysis (see below). There have also been questions raised regarding whether or not the employment figures recorded by the census enumerators included the owneroperator or not. To allow for this possibility we follow previous practice (Sokoloff 1984) and add one to the number of workers employed in our sensitivity analysis (see below). ${ }^{9}$

Although the samples analyzed in this paper are nationally representative of the surviving manuscript schedules, they are not necessarily nationally representative of all manufacturing establishments. Some establishments were missed by careless enumerators or have not survived. However, with one exception-1880—we can presume that such failures were random and, hence, do not bias the results. In that year, certain industries were assigned to special agents who were more knowledgeable about the industry than the average census enumerator. For reasons that are not known, these enumerations were not deposited with the other census data-perhaps they were retained by the enumerators as they wrote their reports (many of which appear in the 1880 census volume on manufacturing) — and the records have yet to be found. ${ }^{10}$ However, some establishments from the "special agent" industries were, in fact, enumerated by regular census agents and (some of) these appear in the 1880 sample. Because the 1880 totals (for example, employment) in the special agent industries were published, it is possible to

\footnotetext{
${ }^{8}$ It was the belief that working capital was under-reported that prompted the inclusion of a separate inquiry on working capital in the 1890 census. However, Sokoloff (1986, p. 713) argues that "a major component" of working capital was included in the pre-Civil War censuses.

${ }^{9}$ The substantive results, however, remain the same if the imputation for the entrepreneurial labor input is not made.

${ }^{10}$ Delle Donne, "Federal Census Schedules".
} 
re-weight the 1880 sample so that it is, in principle, nationally representative (see Atack, Bateman and Margo 2003).

We examine the empirical implications of the two equations given above by estimating regressions of the log of the capital-output ratio and the log of capital intensity. The capital output ratio is measured as the ratio of the reported value of capital to value added (value of outputs minus the value of raw materials). ${ }^{12}$ Capital intensity is the value of capital divided by total reported employment (the sum of male and female employees in 1850 and 1860, and the sum of male, female, and child employees in 1870 and 1880). Below we modify these definitions in particular ways as part of a sensitivity analysis.

To be included in the regression samples establishments had to report positive values of capital, value added, value of raw materials, and employment. We also excluded observations whose industry was not reported and for whom an estimated rate of return to capital invested was unusually high or unusually low, on grounds that capital in such firms was (probably) incorrectly reported (see Atack, Bateman, and Margo 2003).

We pool the samples and estimate regressions of the same general form as those estimated earlier:

$$
\ln y=\alpha_{s}+\alpha_{t}+\alpha_{j}+X \beta+\theta x(\text { South }=1 \text { and Year }>1865)+\varepsilon
$$

\footnotetext{
${ }^{12}$ We use value added because the physical quantity of output was not consistently reported in all of the census samples; see Atack and Bateman (1999).
} 
Here, $\mathrm{y}$ is an outcome variable (the capital-output ratio). The $\alpha$ 's are coefficients of dummy variables for states (s), time period (t), and industry (j); the X's are additional establishment-level controls included in some regressions; and $\varepsilon$ is a random error. If, as the data in section 2 indicate, capital costs increased in the South relative to the North after the Civil War, while wage/rental ratios fell and firms responded to these factor price changes as economic theory predicts, capital use in the southern manufacturing should have declined relative to capital use in non-southern manufacturing -- that is, $\theta$ should be negative.

Table 2 reports the regressions of the log of the capital-to-value added ratio. In the first column, the regression includes dummy variables for states, industries, and years, and the post-bellum South interaction term, but no additional controls. The estimate of $\theta$ is -0.193 , and is highly significant statistically. In the next column we add controls for urban status; dummies for firm size, as measured by employment; and the percent of female workers. Urban status might have influenced capital choice through differences in other factor prices (such as land prices) or because of differential access to financial markets. Differences in female intensity or in firm size may have mattered because these variables were correlated with differences in technology and organizational form, which were also potentially associated with differences in capital use (Goldin and Sokoloff 1982; Atack, Bateman, and Margo 2004). Controlling for these additional variables, however, does not change our substantive finding - indeed, the value of $\theta$ is larger in absolute magnitude (-0.223) and remains highly significant statistically.

In Table 3 we report regressions of the log of the capital-labor ratio. The specification of the regressions is the same as in Table 2. In percentage terms we expect 
to see a larger decline in capital-labor ratios than in capital-output ratios because, as documented in section 2, the wage-rental ratio fell sharply in the South after the War. That is what we observe - the impact on capital intensity is nearly twice as large as the impact on the capital-value added ratio. Adding controls for urban status, firm size, or the use of female labor has almost no effect on the estimated magnitude of $\theta$.

We conducted three sensitivity analyses of these regressions, the results of which are reported in Appendix Table 1. For this purpose, we use the regression specification with urban status and the establishment level controls (column 3 in either Table 2 or Table 3).

First, we modified the definition of the count of workers to take account of the possible under-reporting of the entrepreneurial labor input. As noted above, there is some debate among economic historians as to whether the labor input of owner-operators was counted by census enumerators. To take account of the possibility that it may not have been, we follow Sokoloff $(1984,1986)$ and add one to the count of workers. As can be seen in Panel A of Appendix Table 1, making this adjustment has almost no effect on the estimated value of $\theta$. With the adjustment, the estimate is -0.323 ; without the adjustment, the estimate is -0.320 (from Table 3 ).

Second, we modified the definition of capital to include an imputation for working capital. As noted earlier, it is possible that the pre-1890 manufacturing censuses under-counted working capital. Our imputation is based on the 1890 census and estimates a value for working capital based on the ratio of working capital in 1890 to the gross value of output. Separate imputation ratios are used for industry-state cells, but the same ratios are used for every year (for further details, see Atack, Bateman, and Margo 
2003). This imputation affects our calculation of both the capital labor ratio and the capital-value added ratio. Including the adjustment for working capital slightly reduces the estimated magnitudes of $\theta$ - for example, the coefficient in the capital-value added regression declines in absolute value from -0.223 to -0.156 . However, our substantive conclusion remains the same: capital use fell in southern manufacturing relative to nonsouthern after the Civil War.

Thirdly, we estimated the regressions by industry, rather than pooling the data and including industry dummies. The lowest level of industry aggregation available in the samples is the three-digit SIC (standard industrial classification level) level. Unfortunately, sample sizes are not large enough to reliably estimate the value of $\theta$ for every industry. For six three digit industries, however, we have (approximately) 800 or more establishment level observations. Appendix Table 1 reports the coefficients of the post-bellum South dummy from regressions of the log of the capital labor and capitalvalue added ratios. In all six industries the capital-labor coefficient is negative and is statistically significant in five of six of these. In the case of the capital-value added regressions, the coefficient is negative in five of the industries; in the one case in which the coefficient is positive, it is not statistically significant. Although it would be desirable to examine the effects at the industry level further, it appears that our substantive results from industry-level regressions are the same as from aggregate regressions with industry dummy variables.

In the absence of offsetting changes in total factor productivity, decreases in capital intensity should be associated with decreases in labor productivity. In Table 4 we present estimates of $\theta$ in regressions in which the dependent variable is the $\log$ of value 
added per worker. In column 1 the regression also includes industry and state dummies. In column 2, we add dummy variables for firm size, urban status, and the percent female. The estimated coefficients are negative, implying output per worker in Southern manufacturing declined after the War relative to Northern manufacturing.

In column 3 we add the log of the capital-labor ratio to the regression. If there were no changes in relative total factor productivity - no pure loss of efficiency, in other words, in southern manufacturing - the inclusion of the capital-labor ratio should completely account for the relative decline in labor productivity in the South. In fact, this is the case - when capital intensity is controlled for, the coefficient of the interaction term is close to zero, and is statistically insignificant. Technical efficiency in manufacturing production did not vary across regions, but capital intensity did; and the relative decreases in capital intensity experienced in Southern manufacturing after the War led to a reduction in relative labor productivity.

\section{Conclusion}

Economic historians have documented that the Civil War was associated with a pronounced structural break in the regional pattern of factor prices. In particular, the price of labor relative to capital declined in the South relative to the North, and this decline persisted well after the War was over.

Although previous work has documented these regional shifts in factor prices, the economic consequences have not been addressed. We show in this paper that, in the case of manufacturing, capital use declined in the South relative to the North, and the decline 
in capital intensity was responsible for a corresponding decline in relative labor productivity. Because output per worker in manufacturing is a component of per capita income, the decline in capital intensity documented in this paper was proximate cause of the decline in southern per capita income after the War.

Our analysis in this paper has focused on manufacturing primarily because there are excellent data on this sector and because slavery did not play a major role in southern manufacturing before the Civil War. However, a careful study of farm-level data for the South indicates a decline in capital-labor ratios between 1860 and 1880 (Moen 1992). What remains to be explored is the extent to which any changes in capital intensity in post-bellum southern agriculture can be linked directly to changes in factor prices versus changes in capital use that were caused by shifts in technology - that is, the loss of the gang system - resulting from emancipation. 


\section{References}

Atack, Jeremy and Fred Bateman. 1999. "U.S. Historical Statistics: Nineteenth Century Industrial Development Through the Eyes of the Census of Manufactures: A New Source for Historical Research," Historical Methods: 177-188.

Atack, Jeremy, Fred Bateman, and Robert A. Margo. 2003. "Capital Deepening in American Manufacturing, 1850-1880," National Bureau of Economic Research Working Paper \#9923, Cambridge, MA.

Atack, Jeremy, Fred Bateman, and Robert A. Margo. 2004. "Skill Intensity and Rising Wage Dispersion in Nineteenth Century American Manufacturing," Journal of Economic History 64: 172-192.

Bodenhorn, Howard and Hugh Rockoff (1992) "Regional Interest Rates in Antebellum America" in Claudia Goldin and Hugh Rockoff (eds.) Strategic Factors in Nineteenth Century American Economic History: A Volume in Honor of Robert W. Fogel .Chicago: University of Chicago Press, pp. 159-187.

Bodenhorn, Howard. 2000. A History of Banking in Antebellum America: Financial Markets and Economic Development in an Age of Nation Building. New York: Cambridge University Press.

Cole, Arthur H. 1938. Wholesale Commodity Prices in the United States, 1700-1861. Cambridge, MA: Harvard University Press.

Engerman, Stanley. 1966. “The Economic Impact of the Civil War,” Explorations in Economic History: 176-199.

Engerman, Stanley. 1971. "Some Economic Factors in Southern Backwardness in the 
Nineteenth Century," in J. Kain and J. Meyer, eds. Essays in Regional Economics. Cambridge MA: Harvard University Press.

Davis, Lance E.(1965) “The Investment Market, 1870-1914： The Evolution of a National Market.” Journal of Economic History 25: 355-393.

Delle Donne, D.R. 1973. Federal Census Schedules, 1850-1880: Primary Sources for Historical Research. National Archives and Records Service Reference Information Paper No. 67, General Services Administration, Washington, DC.

Fogel, Robert W. and Stanley. L. Engerman. 1974. Time on the Cross: The Economics of American Negro Slavery. Boston: Little, Brown.

Gallman, Robert. 1986. "The United States Capital Stock in the Nineteenth Century.” In S. L. Engerman and R. Gallman, eds. Long-Term Factors in American Economic Growth, pp. 165-213. Volume 51, Studies in Income and Wealth, Conference on Research on Income and Wealth. Chicago: University of Chicago Press.

Gallman, Robert. 1987. "Investment Flows and Capital Stocks: U.S. Experience in the Nineteenth Century.” In P. Kilby, eds. Quantity and Quiddity: Essays in U.S. Economic History. Middletown, CT: Wesleyan University Press.

Goldin, Claudia. 1979. "'N' Kinds of Freedom: An Introduction to the Issues," Explorations in Economic History 16: 8-30.

Goldin, Claudia and Frank Lewis. 1975. "The Economic Cost of the American Civil War: Estimates and Implications," Journal of Economic History 35: 299-326.

Legler, John and Richard Sylla. 2003. "Integration of U.S. Capital Markets: Southern 
Stock Markets and the Case of New Orleans, 1871-1913.” In S. Engerman, P. Hoffman, J. L. Rosenthal, and K. Sokoloff, eds. Finance, Intermediaries, and Economic Development. New York: Cambridge University Press.

Margo, Robert A. 1995. “The South as an Economic Problem: Fact or Fiction?” In L.

Griffin and D. Doyle, eds. The South as an American Problem, pp. 164-180. Athens, GA: University of Georgia Press.

Margo, Robert A.. 2004. "The North-South Wage Gap, Before and After the Civil War," In D. Eltis, F. Lewis, and K. Sokoloff, eds. Slavery in the Development of the Americas, pp. 324-351. New York: Cambridge University Press.

Moen, Jon. 1992. "Changes in the Productivity of Southern Agriculture Between 1860 And 1880," in R.W. Fogel and S. Engerman, eds. Without Consent or Contract: Markets and Production, Technical Papers, Volume 1, pp.320-350. New York: W.W. Norton.

Ransom, Roger and Richard Sutch. 1977. One Kind of Freedom: The Economic Consequences of Emancipation. New York: Cambridge University Press.

Sokoloff, Kenneth. 1984. "Was the Transition from the Artisanal Shop to the Nonmechanized Factory Associated with Gains in Efficiency? Evidence from U.S. Manufacturing Censuses of 1820 and 1850,” Explorations in Economic History 21: 329-350.

Sokoloff, Kenneth. 1986. "Productivity Gains in Manufacturing During Industrialization: Evidence from the American Northeast, 1820-1860," In Stanley L. Engerman and Robert E. Gallman, eds. Long-Term Factors in American Economic Growth, pp. 679-729. Volume 51, Studies in 
Income and Wealth, Conference on Research on Income and Wealth. Chicago: University of Chicago Press.

Sylla, Richard (1969) “Federal Policy, Banking Market Structure, and Capital Mobilization in the United States, 1863-1913," Journal of Economic History 29: 657-686.

Taylor, George Rogers. 1951. The Transportation Revolution. New York: Rinehart.

United States Treasury . 1866-1885. Annual Report of the Comptroller of the Currency. Washington, D.C.: U.S. Government Printing Office.

Wright, Gavin. 1986. Old South, New South. New York: Basic Books. 
Table 1: The "Treatment Effect" of the Civil War on Interest Rates, the Return on Bank Capital, and Farm Wages: Estimates of $\theta$

\begin{tabular}{|l|l|l|}
\hline Factor Price & Post-bellum Sample Period & Estimate of $\theta$ \\
\hline Interest Rate & $1869-1885$ & 0.209 \\
& & $(0.096)$ \\
\hline Return on Bank Capital & $1869-1885$ & 0.151 \\
& & $(0.039)$ \\
\hline Monthly Farm Wage & $1866-1890$ & -0.291 \\
& & $(0.034)$ \\
\hline
\end{tabular}

Source: Monthly Farm Wage: see Margo (2004, Appendix A, p. 347). The original data give monthly wages for contracts that included board. The value of board, however, can be imputed and added to the reported monthly wage. Interest Rate: Pre-Civil War data are from Bodenhorn and Rockoff (1992) and are data for the "net rate of return on earning assets" for banks in major cities. Data for 1870 to 1885 arer from Davis (1965) and are "net returns on earning assets" of reserve-city banks. Return on Bank Capital: the ratio of dividends paid to bank capital for National Banks as reported in the Annual Report of the Comptroller of the Currency for 1866-1885. Standard errors in parentheses. 
Table 2: Regressions of Log (Capital/Value Added), Coefficients of Post-Bellum South Dummy Variables: Manufacturing Establishments, 1850-1880

\begin{tabular}{|l|l|l|}
\hline $\begin{array}{l}\text { South x Year }> \\
1865\end{array}$ & $\begin{array}{l}-0.193 \\
(0.038)\end{array}$ & $\begin{array}{l}-0.223 \\
(0.038)\end{array}$ \\
\hline $\begin{array}{l}\text { State } \\
\text { Dummies? }\end{array}$ & Yes & Yes \\
\hline $\begin{array}{l}\text { Year } \\
\text { Dummies? }\end{array}$ & Yes & Yes \\
\hline $\begin{array}{l}\text { Industry } \\
\text { Dummies }\end{array}$ & Yes & Yes \\
\hline $\begin{array}{l}\text { Urban + } \\
\text { Establishment } \\
\text { Characteristics } \\
\text { Included? }\end{array}$ & No & Yes \\
\hline Adjusted R & 0.271 & \\
\hline
\end{tabular}

Source: See text and Atack and Bateman (1999). Standard errors in parentheses. 
Table 3: Regressions of Log (Capital/Labor), Coefficients of Post-Bellum South Dummy Variables: Manufacturing Establishments, 1850-1880

\begin{tabular}{|l|l|l|}
\hline $\begin{array}{l}\text { South x Year }> \\
1865\end{array}$ & $\begin{array}{l}-0.336 \\
(0.039)\end{array}$ & $\begin{array}{l}-0.332 \\
(0.039)\end{array}$ \\
\hline $\begin{array}{l}\text { State } \\
\text { Dummies? }\end{array}$ & Yes & Yes \\
\hline $\begin{array}{l}\text { Year } \\
\text { Dummies? }\end{array}$ & Yes & Yes \\
\hline $\begin{array}{l}\text { Industry } \\
\text { Dummies }\end{array}$ & Yes & Yes \\
\hline $\begin{array}{l}\text { Urban + } \\
\text { Establishment } \\
\text { Characteristics } \\
\text { Included? }\end{array}$ & No & Yes \\
\hline Adjusted R & 0.367 & \\
\hline Source: See Tabl 2. Standard & 0.379 \\
\hline
\end{tabular}

Source: See Table 2. Standard errors in parentheses. 
Table 4: Regressions of Log (Value Added/Labor), Coefficient of Post-Bellum South Dummy Variables: Manufacturing Establishments, 1850-1880

\begin{tabular}{|l|l|l|l|l|}
\hline $\begin{array}{l}\text { South x } \\
\text { Year>1865 }\end{array}$ & $\begin{array}{l}-0.144 \\
(0.032)\end{array}$ & $\begin{array}{l}-0.045 \\
(0.029)\end{array}$ & $\begin{array}{l}-0.100 \\
(0.031)\end{array}$ & $\begin{array}{l}-0.009 \\
(0.287)\end{array}$ \\
\hline $\begin{array}{l}\text { State } \\
\text { Dummies? }\end{array}$ & Yes & Yes & Yes & Yes \\
\hline $\begin{array}{l}\text { Year } \\
\text { Dummies? }\end{array}$ & Yes & Yes & Yes & Yes \\
\hline $\begin{array}{l}\text { Industry } \\
\text { Dummies? }\end{array}$ & Yes & Yes & Yes & Yes \\
\hline $\begin{array}{l}\text { Urban + } \\
\text { Establishment } \\
\begin{array}{l}\text { Characteristics } \\
\text { Included? }\end{array}\end{array}$ & No & No & Yes & Yes \\
\hline $\begin{array}{l}\text { Log } \\
\text { (Capital/Labor) } \\
\text { Included? }\end{array}$ & No & Yes & No & Yes \\
\hline Adjusted R & 0.173 & 0.287 & 0.208 & 0.308 \\
\hline
\end{tabular}

Source: See Table 2. Standard errors in parentheses. 
Appendix Table 1: Sensitivity Analyses

A. Estimates of $\theta$ : Adjustment for Entrepreneurial Labor Input and Imputation for Working Capital

\begin{tabular}{|l|l|l|l|}
\hline Entrepreneurial & Working Capital & Ln (K/L) & Ln (K/Q) \\
\hline Yes & Imputed? & $(0.039)$ & Na \\
\hline No & No Adjustment? & -0.320 & \\
\hline Yes & Yes & -0.277 & -0.151 \\
& & $(0.032)$ & $(0.027)$ \\
\hline
\end{tabular}

B. Industry Regressions: Estimates of $\theta$

\begin{tabular}{|l|l|l|l|}
\hline Industry & Ln (K/Q) & Ln (K/L) & Number of \\
& $(0.099)$ & $(0.101)$ & 1,810 \\
\hline Blacksmithing & -0.485 & -0.580 & \\
\hline Flour Milling & -0.253 & -0.383 & 1,873 \\
\hline Sawmills & $(0.106)$ & $(0.098)$ & \\
\hline Boots and Shoes & -0.150 & -0.405 & 2,793 \\
& $(0.088)$ & $(0.076)$ & 1,818 \\
\hline
\end{tabular}




\begin{tabular}{|l|l|l|l|}
\hline Wagons and & -0.264 & -0.453 & 782 \\
Carriages & $(0.208)$ & $(0.207)$ & \\
\hline
\end{tabular}

Source for Panels A and B: see Table 2. Standard errors in parentheses. 